\title{
THE CHEMICAL COMPOSITION AND THE ACID BASE BALANCE OF ARCHIDORIS BRITANNICA
}

\author{
By R. A. McCance, M.D., Ph.D. and M. Masters, B.Sc. \\ Biochemical Department, King's College Hospital, London
}

(Plate XVII)

The unusual amounts of calcium and magnesium discovered by McCance \& Shackleton (I937) in the nudibranch, Archidoris britannica, raises a number of interesting questions: Why are the metals there in such quantities? What, if any, is their function? With what are they combined? It was accordingly decided to make a more detailed study of this gastropod and to supply an answer at any rate to the last question.

The animals were obtained alive from the Marine Biological Association at Plymouth. About forty animals have been used for this work, and the practice has been to get about eight sent at one time and to pool them for analysis. The batches have differed little in composition or behaviour. The animals were prepared for investigation as follows: Each was separately removed from sea water, rinsed in distilled water and dried quickly on a cloth. A circular opening was then made in the back and the whole of the visceral mass removed and placed in a separate dish. The visceral cavity was then rinsed out with distilled water and dried. A characteristic feature of the animals is the enormous quantity of mucus secreted after this treatment. On one occasion, for instance, $80 \mathrm{~g}$. of body tissue secreted $24 . \mathrm{I} \mathrm{g}$. of mucus in about $\mathrm{I} \frac{1}{2} \mathrm{hr}$. As first secreted the mucus is very viscous but after $2 \mathrm{hr}$. or so becomes much more fluid and can be withdrawn from the dish by a pipette. The viscera secrete little or no mucus.

\section{Methods}

Water was determined by drying to constant weight at $100^{\circ} \mathrm{C}$; fat by weighing the ether-soluble material removed by I $2-24 \mathrm{hr}$. soxhlet extraction. Glycogen was determined by a micro-Pfluger method (Lawrence \& McCance, I93I). The methods used for total nitrogen, phosphorus, chlorine, sodium, potassium, calcium, magnesium, iron and copper have been described by McCance \& Shipp (1933) or McCance, Widdowson \& Shackleton (1936). Inorganic sulphate was determined as $\mathrm{BaSO}_{4}$. Carbonates and bicarbonates in the solid tissue were decomposed with acid at $37^{\circ} \mathrm{C}$., and the $\mathrm{CO}_{2}$ evolved was carried over by a stream of air into potash bulbs and determined gravimetrically. The conventional precautions were taken and the method gave satisfactory results on pure chemicals. $\mathrm{CO}_{2}$ in the mucus was determined by 
Van Slyke's technique (Harrison, 1937). Strontium was estimated by precipitation of the oxalate and titration of the latter with permanganate. The calcium was previously removed by treating the mixed nitrates with alcohol (Treadwell \& Hall, 1935). Fluorine was determined by Willard \& Winter's (I933) method. $p \mathrm{H}$ values were determined colorimetrically in capillary tubes by a slight modification of the B.D.H. Capillator method. Glycogen was determined on fresh material, sampled immediately after removal of the viscera. All analyses of mucus were made on the liquid material; other analyses, except where expressly stated, were carried out on dried material. All analytical procedures, including the initial sampling, were carried out in duplicate.

\section{RESULTS}

Before entering into any presentation or discussion of results it is advisable to state that the $p \mathrm{H}$ of these animals, of the mucus they secrete and of their vascular fluids appears to be the same as that of sea water.

\section{Table I. Composition of the Body Tissue of ARChidoris bRITANNICA}

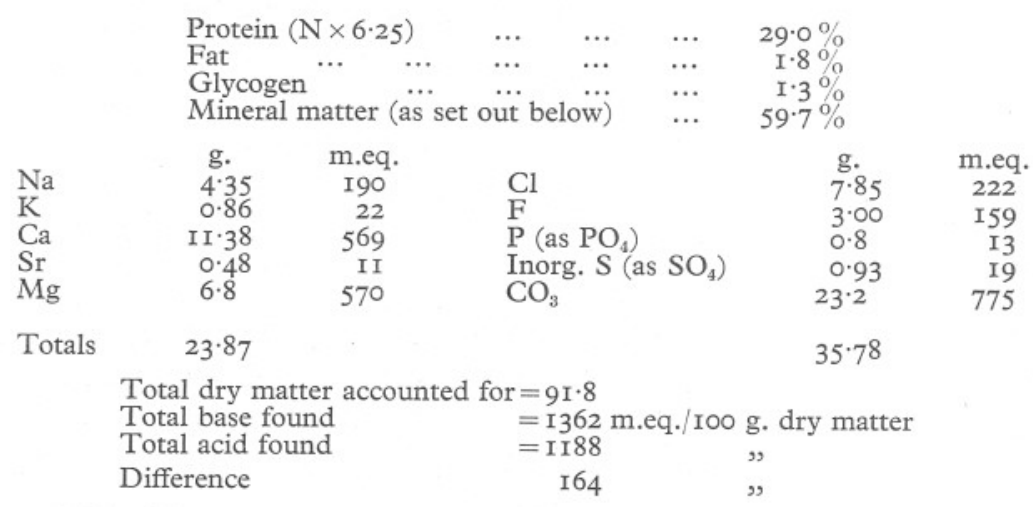

N.B. Silicon has been looked for and found to be present only in traces.

In preliminary experiments animals were prepared as already described. Shavings of skin and superficial tissue from the back and sides, the remainder of the body tissue with its secreted mucus, and the visceral mass were analysed separately for metallic radicles. This made it clear that the body and the skin, but not the visceral mass, contained the large concentrations of calcium and magnesium. It is unnecessary to give these figures in detail, for similar figures for the guts and body were obtained on other batches of animals, and are given later (Tables I \& II). The skin shavings differed inappreciably from the body tissue except that they contained more sodium, possibly due to incomplete removal of sea water, and rather more iron and copper. Table I gives the composition of mixed skin and body tissue as determined by analysis. The material was weighed out before the secretion of mucus had really begun. All con- 
stituents, however determined, are calculated as a percentage of the dry matter which itself formed $17.6 \%$ of the total fresh weight.

The composition of this tissue is very unusual; regarded from mammalian standpoints it is fantastic. The most striking features are perhaps: (I) The total amount of mineral matter in a tissue possessing no obviously calcified structure such as a shell or gastric plates. The amount of calcium and magnesium is particularly striking, and it is to these elements that the great excess of mineral matter is due. (2) The presence of $3 \%$ of fluorine. This element was recognized chemically and determined quantitatively before Fox \& Ramage's (I93I) report of its presence by qualitative spectrographic analysis

Table II. Composition of the Body Tissue after Removal of the Secreted Mucus, of the Mucus itself and of the Visceral Mass

All data refer to fresh weight.

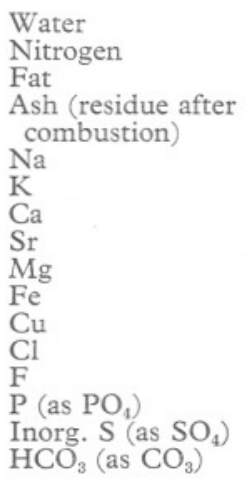

\begin{tabular}{|c|c|}
\hline $\begin{array}{r}B \\
83 . \mathrm{I} \mathrm{g.}\end{array}$ & \\
\hline $\mathrm{I} \cdot \mathrm{O}$ & , \\
\hline I $\cdot 8$ & " \\
\hline $560 \mathrm{~m}$ & $/ 100 \mathrm{~g}$ \\
\hline I36 & , \\
\hline 2000 & , \\
\hline 85 & ", \\
\hline 930 & , \\
\hline$I \cdot 3$ & , \\
\hline $2 \cdot 4$ & ", \\
\hline 953 & , \\
\hline 410 & " \\
\hline I 26 & , \\
\hline $42 \cdot 2$ & " \\
\hline 4500 & , \\
\hline
\end{tabular}

\begin{tabular}{|c|c|}
\hline $\begin{array}{r}N \\
96.0 \mathrm{~g} . \\
0.048\end{array}$ & cus \\
\hline $3200 \mathrm{~m}$ & IOO c.c. \\
\hline 975 & 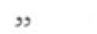 \\
\hline $5 \mathrm{I}$ & , \\
\hline 53 & , \\
\hline I36 & פ, \\
\hline${ }^{1} 740_{T}$ & r o \\
\hline $32 \cdot 7$ & צ' \\
\hline
\end{tabular}

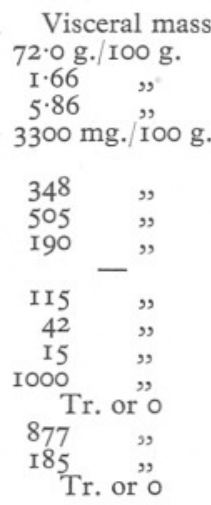

was discovered. (3) The presence of strontium. This element might have been extraordinarily difficult to detect had it not been for the work of Fox \& Ramage.

Only some $92 \%$ of the dry matter has been accounted for, which may very well be due to the factor 6.25 not being correct for the proteins in Archidoris. The amount of nitrogen in mucin (submaxillary) is stated to be only II $2 \%$ and of mucins generally I I-I3\% (Oldfeldt, I936). The body of Archidoris certainly contained large amounts of mucus so that the factor 6.25 is probably too low for this tissue. Hence the amount of protein $(29 \%)$ given in Table I may be less than the actual amount present. On the other hand, there is a difference of I64 m.eq. between the total inorganic acid and base which have been accounted for (Table I) so that some of the missing solids may be organic acids. If so their average combining weight must be quite low, i.e. of the order of 53 .

An important biological consideration is the state of combination of the $\mathrm{CO}_{2}$ in the living tissue, i.e. is it present as carbonate or bicarbonate? 
To settle this, $\mathrm{CO}_{2}$ was determined in one batch of animals $(a)$ in the fresh state, $(b)$ after drying to constant weight at $100^{\circ} \mathrm{C}$. The results, calculated to a fresh-weight basis, were as follows: $\mathrm{CO}_{2}$ in the living state, 4. I4 g./I00 g., and after drying at $100^{\circ} \mathrm{C}$., 4. II g./I00 g. There was therefore very little loss of $\mathrm{CO}_{2}$ on drying and it is concluded therefrom that the initial form of combination was the carbonate. This is supported by the histological examinations.

Work has also been carried out on the composition of the mucus and of the visceral mass. It is recognized that the analysis of the last is not of the same value as an analysis of the individual organs would have been, but its composition makes an interesting comparison with that of the body tissue and the mucus. The results calculated in each case on the basis of fresh weight are given in Table II. It might have been better to calculate some of the inorganic constituents to a dry-weight basis and others as a percentage of the body water, but this can be done by those interested from the figures given. The animals used for the compilation of Table II were not the same as those

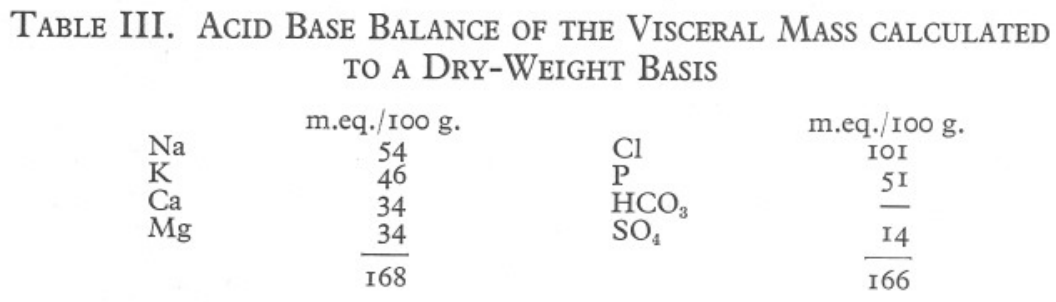

used for Table I. The data in Table II are in most instances the mean results obtained from two different batches of animals. It will be observed that the mucus and the visceral mass differ radically in composition from the body cissue. The differences in water, nitrogen and fat are in the direction, and of the order to be expected. The differences in the mineral constituents require more comment. The general inorganic make up of the mucus resembles sea water, and it is evidently composed essentially of the mixed chlorides of sodium, potassium, calcium and magnesium. Some sulphates were no doubt present, but were not determined owing to lack of material. It is a true extracellular fluid in containing sodium rather than potassium salts, the potassium in the animal evidently being associated, as one would expect, with the cellular tissue of the body and the visceral mass. The inorganic constituents of the body have already been described. The mineral matter of the visceral mass, which is probably mainly glandular tissue, makes a strong contrast. The calcium is relatively trifling in amount, potassium occupies a much more prominent role, and chlorides and phosphates make up the acid radicles. Carbonates are conspicuous by their absence. The acid base balance of the visceral mass is given in Table III for comparison with Table I. 


\section{Discussion}

There is no doubt that the striking feature of this animal is the enormous concentrations of calcium and magnesium to be found in the body tissues and the acid radicles with which they are combined. Histological preparations of the animal, fixed in absolute alcohol, show that the subcutaneous tissue is very loose, and in sections which have been treated with acid there are a large number of tubular spaces (Pl. XVII, fig. I). These spaces, which vary considerably in size and number, may be collected together in groups of sixteen or more, or scattered diffusely through the tissue. They are not lined by a continuous layer of cells, and the walls are often very thin and appear quite acellular. Occasionally the spaces are filled with what appears to be a radially arranged framework (Pl. XVII, fig. 4). Sections prepared without any contact with acid show the spaces filled with heavily mineralized material somewhat resembling casts of the renal tubules, which in cross-section are marked by concentric lines, and occasionally by radial fracture (Pl. XVII, fig. 3). Where the spaces have been cut longitudinally the mineral masses appear columnar with longitudinal striations. Sometimes the longitudinal columns show transverse fractures. These appearances suggest that the mineral material has been laid down by continuous deposition. Examined superficially the mineral deposits may resemble large crystals. The significance of these mineral agglomerations must remain for the present one of the many unsolved problems of mineral metabolism, but there are one or two points worthy of consideration. In the first place it is difficult to believe that to carry about so much mineral matter and to derive no protection therefrom can possibly have much survival value. Archidoris britannica is considered to have lost its shell somewhere in the course of its evolution. Possibly it never thereafter acquired the necessary excretory mechanism for dealing with its ingested calcium. The loss of the property to form a shell must after all have a profound influence upon an animal's mineral metabolism, and in this connexion it is worth noting the gastric plates of certain other gastropods with very reduced shell coverings. On the other hand, calcified spicules are found in animals which never possessed a shell (e.g. didemnid tunicates and even Alcyonium), so that there may be no real connexion between the two. It is possible that the retention of magnesium is in some way associated with that of calcium. It is suggestive that the two metals should be present in both the solid tissues in equimolecular amounts (Tables I and III). This, however, may be merely a species peculiarity, for it is not the case in forunna tormentosa (Cuvier) (McCance \& Shackleton, I937) where the magnesium exceeds the calcium, or in Littorina littorea (an animal with a thick shell) where certain of the body tissues may contain much higher concentrations of magnesium than of calcium (McCance \& Shipp, I933). It is perhaps worth noting that the land snail has been found to contain more magnesium than other land animals, and much more magnesium than calcium (Takamatsu, 
I936). It seems just conceivable that these large quantities of carbonates are accumulated for their buffering action.

The authors are indebted to L. R. B. Shackleton and A. W. Haynes for assistance at various stages of the investigation, and also to Dr Robison, Miss Murray, Mr D. A. Webb and others for suggestions made at various times. Certain of the costs were defrayed by the Medical Research Council.

\section{SUMMARY}

The body of Archidoris britannica contains very high concentrations of calcium and magnesium which appear to be combined mostly with $\mathrm{CO}_{3}$ and fluoride. The bulk of these materials are in solid deposits throughout the submucous tissue. Sodium chloride and potassium phosphate account for most of the residual mineral matter.

The mucus secreted by the body has an inorganic composition resembling sea water.

The visceral mass contains only one-tenth as much calcium and magnesium as the body. The predominating bases are potassium and sodium and the acid radicles are essentially chlorides and phosphates.

\section{REFERENCES}

Fox, H. M. \& Ramage, H., I93I. A spectrographic analysis of animal tissues. Proc. Roy. Soc. B, Vol. I08, p. I57.

Harrison, G. A., 1937. Chemical Methods in Clinical Medicine, p. 197. Churchill, London.

LAWRENCE, R. D. \& MCCANCE, R. A., I93I. The effect of starvation, phloridzin, etc., on the distribution of glycogen in the rat. Biochem. Fourn., Vol. 25, p. 570 .

McCANCE, R. A. \& ShackLeton, L. R. B., I937. Metallic constituents of marine gastropods. Fourn. Mar. Biol. Assoc., Vol. xxII, p. 269.

MCCANCE, R. A. \& ShIPp, H. L., I933. Chemistry of flesh foods and their losses on cooking. Spec. Rep. Ser. Med. Res. Counc., No. I87.

- 1933. Magnesium and other inorganic constituents of some marine invertebrates. Fourn. Mar. Biol. Assoc., Vol. xIX, p. 293.

McCance, R. A., Widdowson, E. M. \& Shackleton, L. R. B., 1936. The nutritive value of fruits, vegetables, and nuts. Spec. Rep. Ser. Med. Res. Counc., No. 213.

OldFELDT, C. O., I936. Physikalisch-chemische Untersuchungen an einigen Mucinen und Mucoiden. Hoppe-Seyl. Z. f. Physiol. Chem., Vol. 240, p. 249.

TAKAMATSU, M., 1936. Kalk und Magnesiumgehalt im Fleisch der verschiedenen Tiere. Hoppe-Seyl. Z. f. Physiol. Chem., Vol. 238, p. 99.

Treadwell, F. P. \& Hall, W. T., 1935. Analytical Chemistry, Vol. 2, p. 93. John Wiley, New York.

WILlARD, H. H. \& WINTER, O. B., I933. Volumetric method for the determination of fluorine. Indust. Eng. Chem. Anal. Ed. Vol. 5, pp. 7-IO. 


\section{EXPLANATION OF PLATE XVII}

Fig. I. Section of Archidoris britannica which has been treated with acid, showing the large number of tubular spaces. Stained with haematoxylin and eosin. $\times$ I 25 .

Fig. 2. Section of Archidoris britannica prepared without any contact with acid and showing the mineral deposits. Stained with haematoxylin and eosin. $\times$ I25.

Fig. 3. Section of Archidoris britannica prepared without any contact with acid, showing the mineral deposits and the concentric markings on those deposits which have been cut transversely. Stained with Van Giesen. $\times 300$.

Fig. 4. Section of Archidoris britannica which has been treated with acid, showing the spaces filled with what appears to be a radially arranged framework. Stained with methylene blue. $\times 300$. 


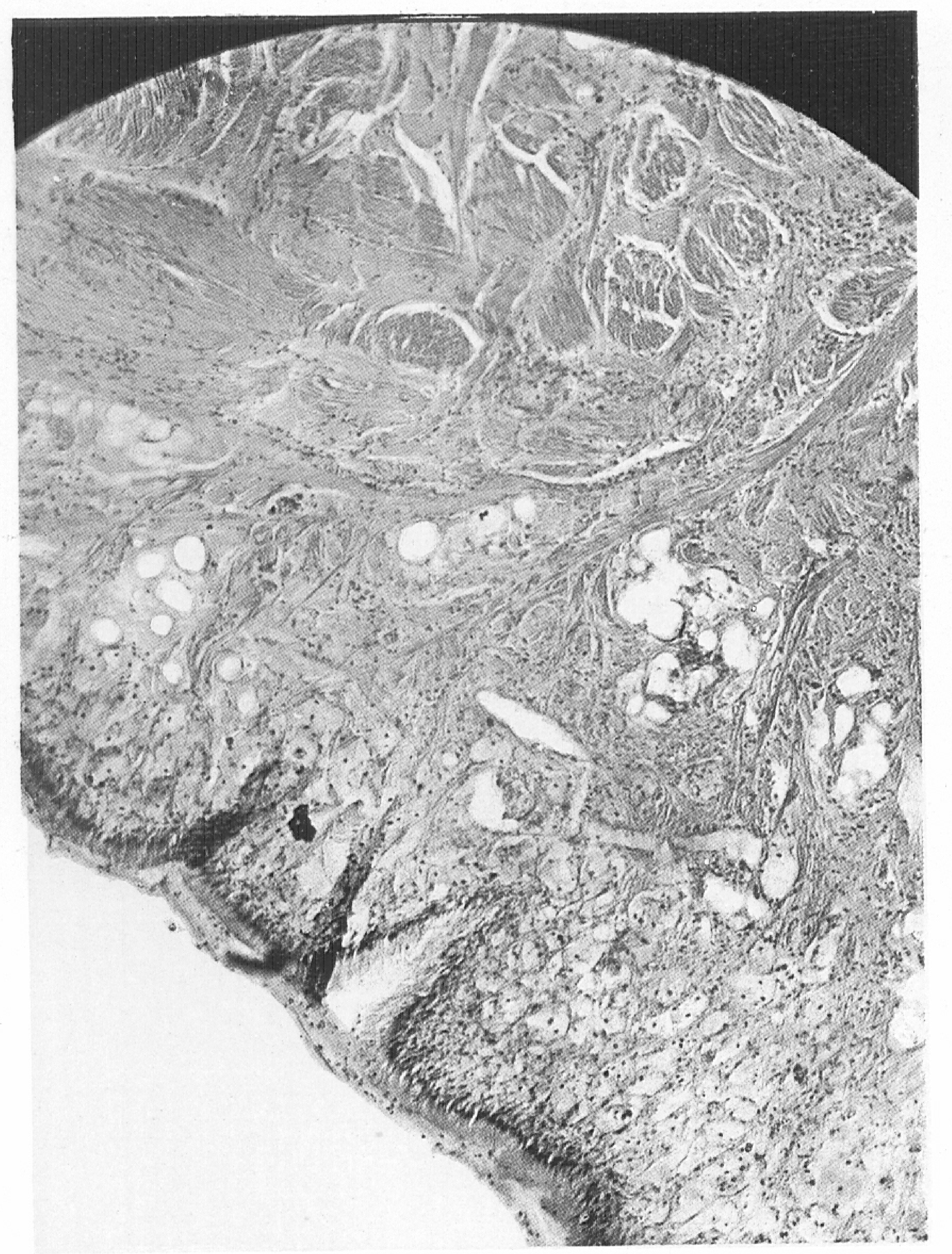

1.

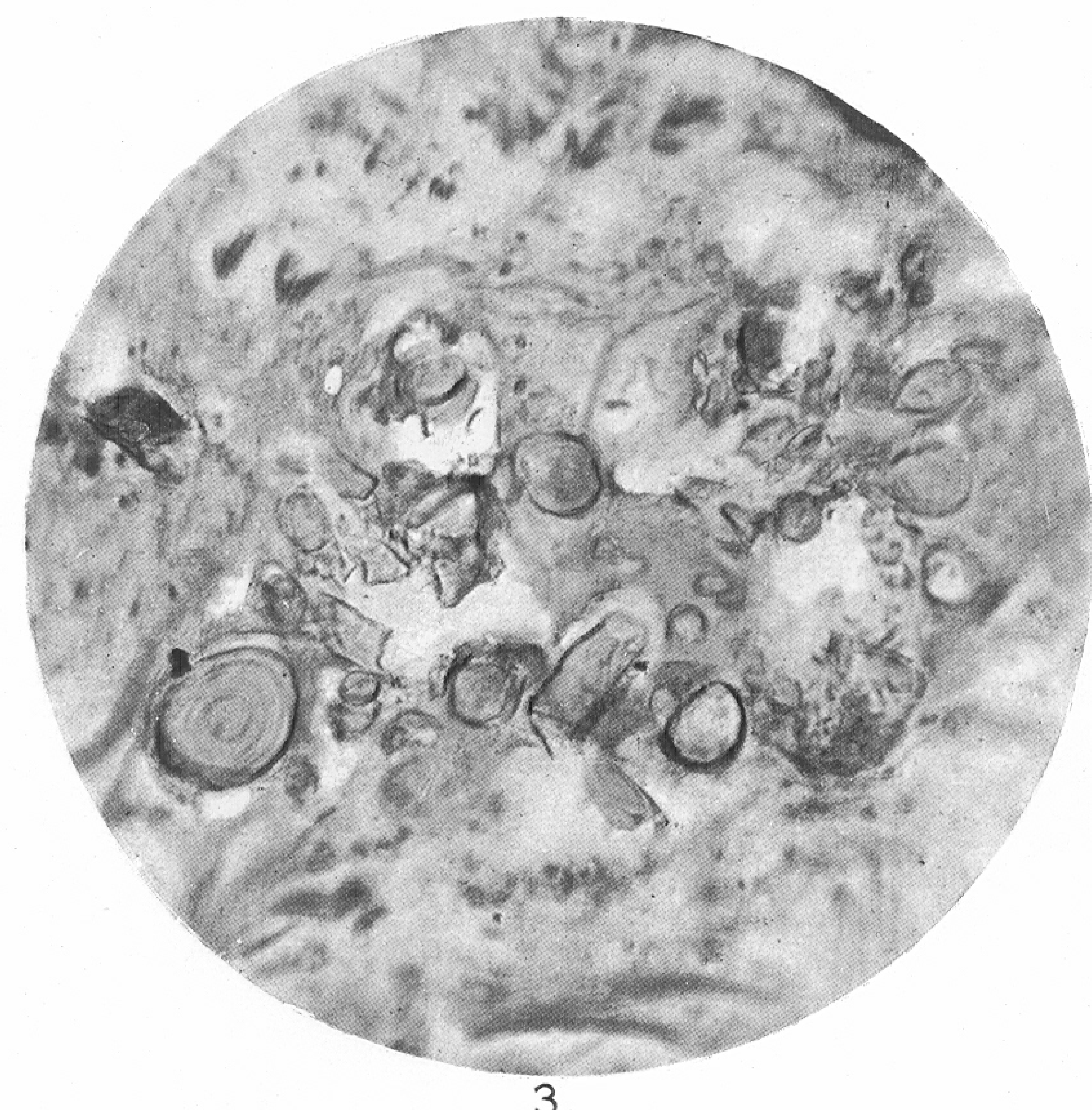

Photo. Russell C. Vernon.

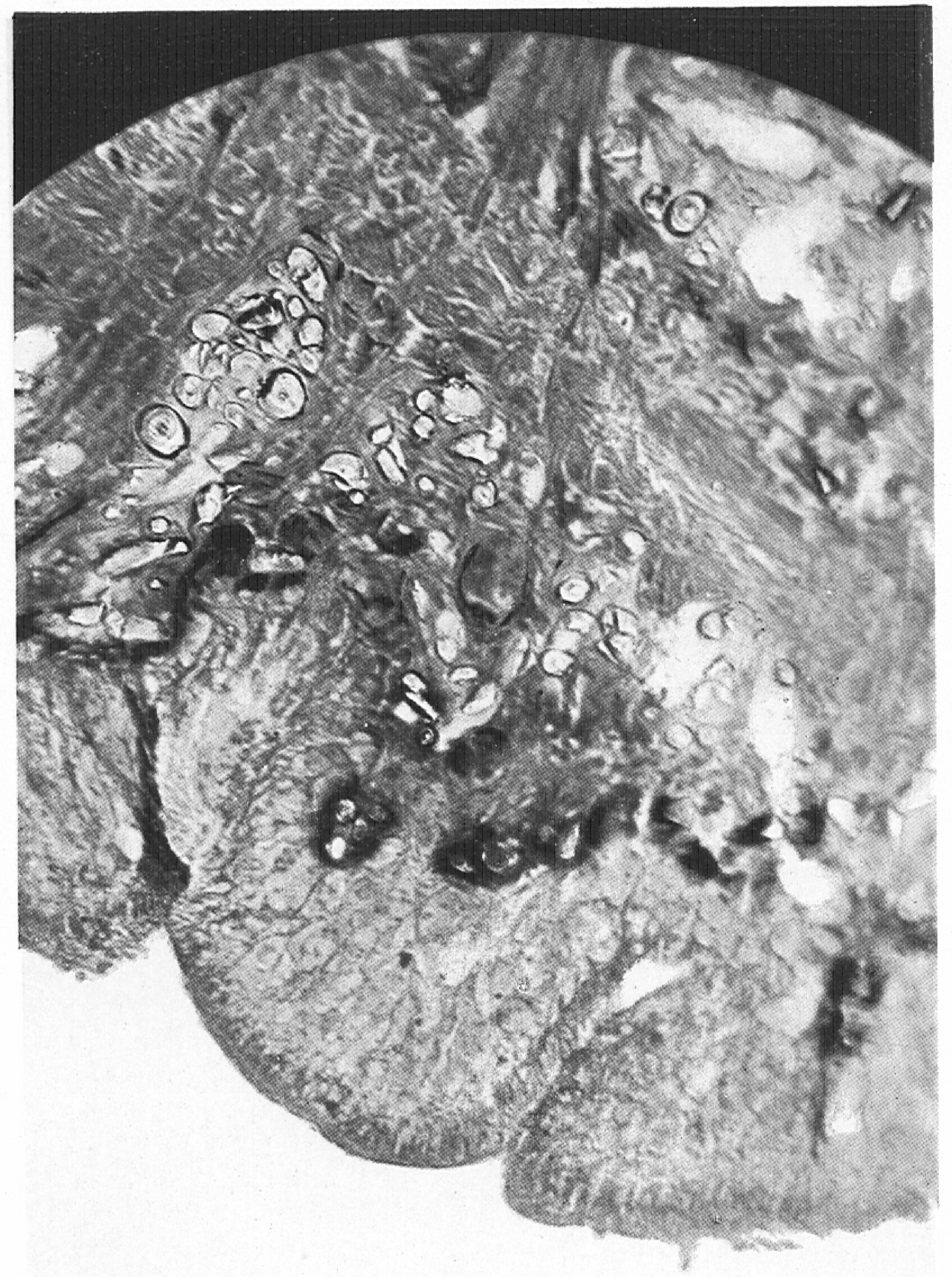

2.

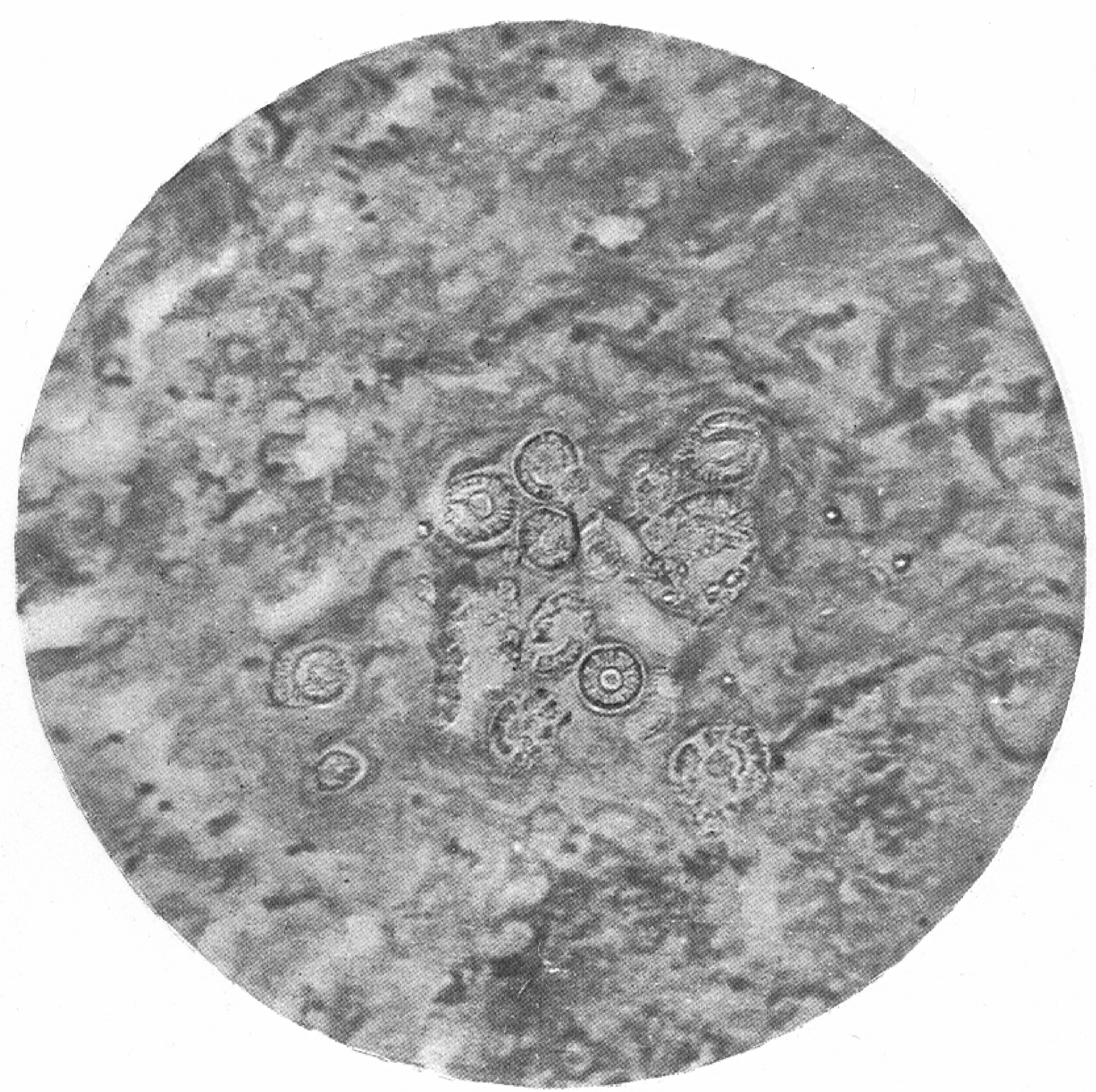

4.

John Bale. Sons \& Curnow, Lt L London. 